\title{
Effect of Marketing Strategies on the Dairy Value Chain Returns and Food and Nutrition Security in Bungoma County, Kenya
}

\author{
Nabiswa Patrick Koyi ${ }^{1}$, Prof. Donald N. Siamba ${ }^{2}$ \\ ${ }^{I}$ PhD Student in the Department of Disaster Management and Sustainable Development of Masinde Muliro \\ University of Science and Technology \\ ${ }^{2}$ Department of Agriculture and Veterinary Sciences \\ Kibabii University
}

\begin{abstract}
Dairy farming is ranked highly among the agricultural enterprises in Bungoma County due to its potential to enhance food security and alleviate poverty. Despite the huge livestock resource base, the poverty index for Bungoma County remains high (53\%). The study investigated the Effect of Marketing Strategies on the Dairy Value Chain Returns and Food and Nutrition Security in Bungoma County, Kenya. This study was anchored on Porter's Value Chain theory. The study adopted correlational research design. The sample size comprised of seven hundred and eleven (711) respondents representing key dairy value chain actors. Respondents were sampled using random, census and purposive sampling. The study used semi-structured questionnaires, key informant interview schedules, focus group discussion and observation schedules to collect primary data. A Pilot study was carried out in Kimilili Sub-County and then sets of data analysed using Cronbach alpha method which yielded an alpha value of 0.824. Validity of research instruments was tested using content, construct and face validity. The data obtained was analysed using descriptive and inferential statistics. The study found informal marketing of dairy products was common among dairy farmers. Other marketing strategies were cooperative societies and contract marketing. Marketing strategies were influenced by price, access to market, availability of market information and demographic characteristics. On food security and nutrition, the months they faced severest food shortage were between January and March, as well as between April and June. The households were not able to eat the kinds of foods preferred, ate fewer meals in $a$ day and spent whole day and night without eating anything. There was significant relationship between marketing strategies and dairy value chain returns on food and nutrition security with marketing strategies significantly explaining $27.3 \%$ of the variations in the food and nutrition security. The study concluded that marketing strategies of dairy products has significant effect on food and nutrition security. The study therefore recommends concerted effort to improve returns from informal marketing to facilitate food security and sustainable development
\end{abstract}

Key Words: Dairy Value Chain Returns, Food and Nutrition Security, Marketing Strategy, Sustainable Development

\section{Introduction}

Food security is a situation in which all people, at all times, have physical and economic access to sufficient, safe and nutritious food to meet their dietary needs and food preferences for an active healthy life (FAO, 2007). It is affected by a complexity of factors. These include unstable social and political environments that preclude sustainable economic growth, war and civil strife, macroeconomic imbalances in trade, natural resource constraints, poor human resource base, gender inequality, inadequate education, poor health, and natural disasters, such as floods and locust infestation, and the absence of good governance. All these factors contribute to either insufficient national food availability or insufficient access to food by households and individuals (FAO, 2014, 2015). The root cause of food insecurity in developing countries is the inability of people to gain access to food due to poverty (IAC, 2004; Wabwoba, et al., 2016).

Dairy sub-sector plays an important role as a source of income, which farmers can use for purchasing food and other household assets. It has been considered as an important avenue for rural development in developing countries through its contribution to increases in dairy products production, income generation from sales of the products, provision of jobs and transfer of money from urban to peri urban and rural areas (Paris, 2000; Kristensen et al., 2004). In Kenya, dairy production aims to achieve multiple objectives, namely; to improve food security, support crop production, build capital assets and generate cash income. The dairy industry of Kenya forms a significant part of the rural economy in the country accounting for $14 \%$ of agricultural GDP as well as being the primary source of livelihood for many smallholders who account for over $70 \%$ of the total marketed milk in the country (IFAD, 2015; Kibiego, et al., 2015).

Dairy value-chain development projects have increasingly been promoted as a way of linking smallholder dairy farmers to markets. These projects aim to increase the productivity and efficiency of actions 
and organizational links that move a product or service from conception through a series of steps, including production, processing, marketing, and delivery to final consumers and finally through consumption and disposal (Rubin and Manfre, 2012). These efforts attempt to link smallholder dairy farmers to markets by shifting traditional farming strategies toward increased production for the market; by providing market information; by organizing farmers into groups, associations, or cooperatives; and by coordinating contract farming and out-grower schemes (Njuki et al., 2011).

Dairy marketing is one of the key determinants to the development of dairying in sub-Saharan Africa countries (Tsegay \& Zereu, 2015). Because marketing situation of dairy products is a determining factor for types of production systems which would be practiced, it determines returns from dairy farming. Moreover, marketing system of dairy products is a matter of benefit/gain whereby producers exchange their animal and dairy products for cash. The cash is used for acquiring goods and services which they do not produce by themselves. So, marketing strategies of dairy products must be addressed if dairying is to realize its full potential to provide food and nutrition security and sustainable development. Hence the study was undertaken to assess effect of marketing strategies on the dairy value chain returns and food and nutrition security in Bungoma County, Kenya.

\section{Research Methods and Materials}

This study was carried out in Bungoma County. It borders Republic of Uganda to the north-west, Trans Nzoia to the east, Busia County to the west and south-west and Kakamega to the south. The County has nine administrative Sub-counties, namely Mt. Elgon, Kimilili, Webuye West; Webuye East, Tongaren, Kabuchai, Kanduyi, Sirisia and Bumula (see Figure 1). Bungoma County is served by the main Webuye-Kisumu road and by the Webuye-Malaba road. The tarmacking of Kamukuywa-Kapsokwony road has really opened Mount Elgon Sub-county which is one of the biggest catchment areas of milk production in Bungoma County. However, the larger part of the County is served by Murram and earth roads.

It covers an area of 3,032.2 square Kilometres with a population of about 1.6 million people. The County's poverty rate, based on Kenya Integrated Household Baseline Survey (KIHBS, 2005/06) is 52.9\%. The main economic activity is agriculture. About 80 per cent of the labour force in the county is engaged in agriculture and livestock activities, which is dominated by small scale farming. The County has good land and soil suitable for maize and sugarcane farming. Subsistence farming is practised by majority of the small scale farmers. However, some residents have adopted tea growing and sugarcane; hence form of cash crops that earn substantial income. The socio-economic status of most residents is low which is depicted by semi-permanent houses and high unemployment due to high school dropout rates.

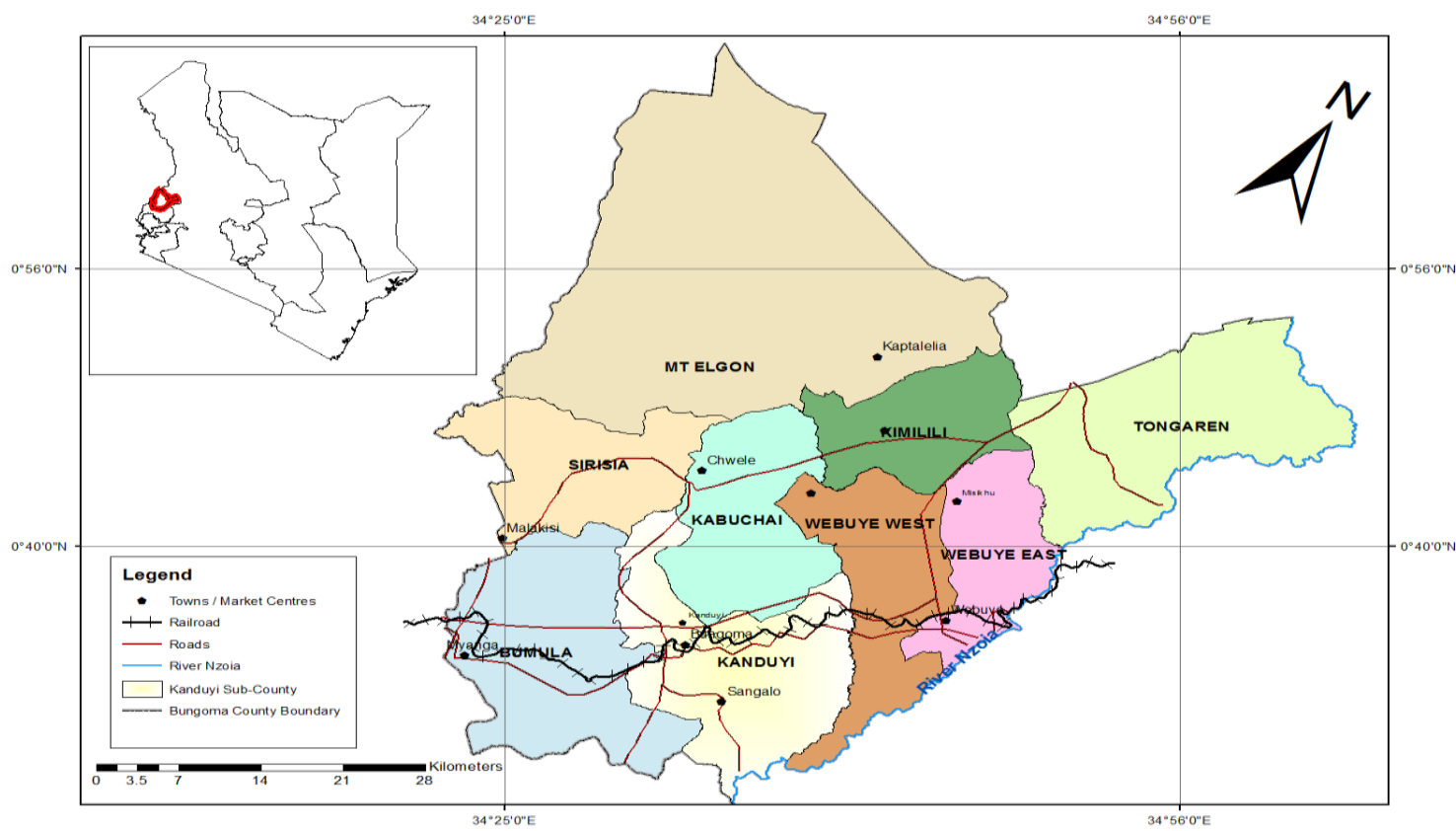

Figure 1: A Map of Bungoma County Showing Its Sub-Counties

The study adopted correlational research design. Correlation research aims to ascertain if there are significant associations between dairy value chain returns and food and nutrition security. Multi-stage random sampling was used to group the 10,062 farmers spread in the eight sub-counties, then followed by selecting a 
sample within each chosen cluster. Multi-stage random sampling involves selecting a sample in at least two stages. In the first stage, large groups or clusters are selected (Rahmantya, 2009).

The sample size of farmers in the seven (7) Dairy Cooperative Societies was obtained using coefficient of variation. Nassiuma (2000) asserts that in most surveys or experiments, a coefficient of variation in the range of $21 \%$ to $30 \%$ and a standard error in the range of $2 \%$ to $5 \%$ is usually acceptable (Eq. 1 ).

$$
S=\frac{N(C v)^{2}}{(C v)^{2}+(N-1) e^{2}}
$$

Where $\mathrm{S}=$ the sample size

$\mathrm{N}=$ the population size $(10,062)$

$\mathrm{Cv}=$ the Coefficient of Variation $(0.21)$

$\mathrm{e}=$ standard error $(0.02)$

Therefore, the sample size was:

$$
\mathrm{S}=\frac{10,062\left(0.21^{2}\right)}{0.21^{2}+(10,062) 0.02^{2}}=109.066 \quad \approx 110 \text { farmers }
$$

$\mathrm{S} \quad=110$ Farmers $+20 \%$ of non-responsive farmers or spoilage of data instruments, therefore sample size of farmers $=132$ farmers

Purposive sampling technique was used to select the 7 managers of Dairy Cooperative Societies, 19 representatives of Agrovets and 24 Livestock Officers from eight sub-counties. 48 Cooperative Officers, 17 representatives of Financial Institutions and 6 representatives of Capacity Building Institutions were selected using census sampling technique. 84 Milk vendors, 102 Transporters and 110 Consumers were selected using simple random sampling. The study also sampled 160 respondents for 16 FGDS comprising of 10 discussants each. This made the total number of respondents to be 711 .

Primary data was collected using questionnaire, interviews guide, FGD, and observation checklist. Validity of the research instruments was done by presenting the instrument to the supervisors to evaluate the applicability and appropriateness of the content, clarity and adequacy of construction of the instrument and suggestions made, and modified appropriately. Pilot study was conducted in Kimilili Sub-County to test reliability of the research instruments. The pilot study yielded a Cronbach alpha coefficient of 0.824 . Quantitative data was analysed descriptively using frequencies and percentage and inferentially using spearman Rank Correlation and multiple linear regressions at the significance level was 0.05 . The findings were presented in form of tables and charts. Qualitative data from the in-depth interviews and focused group discussion was also analysed using content analysis and presented in form of verbatim and narrations.

\section{Findings and Discussion}

Results in Figure 2 show that majority of farmer respondents marketed their milk informally accounting for $67.92 \%$ (72) while $33.02 \%$ (35) marketed their milk formally. A Chi Square test conducted revealed there was a highly significant $(\mathrm{p}<0.05)$ variation in the marketing strategies adopted by sampled dairy farmers $\left(x_{1}^{2}\right.$ oco $\left.=12.794\right)$.

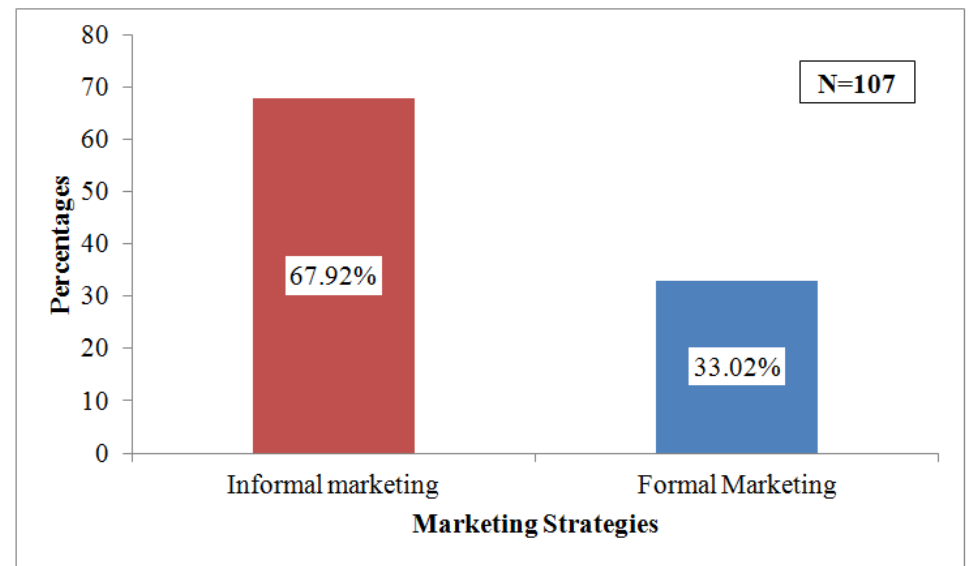

Source: Field Data, 2016

Figure 2: Dairy Products Marketing Strategies in Bungoma County, Kenya

\section{Informal Marketing Strategies}

The study established that two strategies are used by dairy farmers in marketing of their milk products informally. These were direct marketing where farmers sold their milk to end users; and through itinerant where 
the farmers sold their milk to middle men who later sold it to consumers in the local market or to the milk processors. The results revealed that at least all the farmer respondents sold all or part of their milk produce in informal market. Of these, $58.8 \%$ sold more than half of their milk directly to consumers while $41.2 \%$ sold their milk to middlemen who later sold it to consumers or other local milk processors.

The results from focus group discussions revealed that dairy farmers preferred selling their milk through informal channels such as street vendors, hawkers who use bicycles to hawk milk, neighbors, local hotels and restaurants. The milk sold using this strategy was mainly raw milk and in some cases sour milk (Mala/Lala). This group usually buys the milk from farms then resells it at profit. However, interview with cooperative officers revealed that this group of traders had negative effect on milk marketing as they were found to adulterate the milk by adding water and other chemicals so that they can earn more. They also noted that, consumers would prefer to buy milk from farmers due to quality of milk. Some of them would visit the farmers during milking time to ascertain the quality of milk they buy.

The end user for informal market consists mainly of low income earners and less educated consumers. In some cases, the buyers would trade milk with farm produce such as maize or beans in exchange for milk. This increases the food availability for dairy farmers especially those who have small pieces of land. However, on the flipside, this kind of marketing of dairy products limits the income from dairy farming. The only main product that is sold from dairy farming is milk and during dry seasons when the milk production is low, the income from milk reduces and during wet seasons when supply is high, the prices goes down also resulting to low income. Despite prompt payment from informal marketing, the quick cash fails to meet the requirement of cumulative capital for dairy investments and sustainable development. The key players in informal marketing of milk usually transport the milk in low cost equipment such as jerry cans, milk cans on pick-up trucks, motorcycles and bicycles and often deliver milk directly to the consuming household. They have no access to milk coolers hence oftenly boil milk to maintain its quality and reduce spoilage. Further, in informal channel, 20-litre plastic jerry cans are preferred over aluminium by vendors to transport milk from various centers to major collection points. This is because, Plastic jerry cans are cheap to buy and easy to load on the bicycle while maximizing the carrying capacity. However, such containers are not of food-grade standard and this practice is against regulations on milk handling which emphasizes the use of aluminium cans. The findings of this study agree with ADCE (2011) which indicated that over $90.5 \%$ of the marketed milk is traded through traditional informal markets. According to DDA (2010), informal milk marketing channels' weaknesses override its strengths. It is characterized by lack of milk collection infrastructure, limited quality control, lack of facilities for pasteurization and hygienic handling of milk, adulteration of milk with water and other chemicals. Elepu (2006) further noted that informal channel participants use poor quality vessels in transportation of milk, for example, jerry cans, boiling of milk in unhygienic environments, lack of credit and difficult to monitor product quality standards. However, irrespective of the inefficient quality milk handling associated with raw milk traders, MAAIF (2004) noted that trade in unprocessed milk has had a tremendous impact in mopping surplus milk from dairy farmers especially during the rainy season. This makes the so called informal channel an important source of income to many people and a serious competitor to the formal channel (DDA, 2010).

\section{Formal Marketing Strategies}

The formal marketing of milk consists of selling milk to marketers through some form of agreement which can either be verbal or written. The formal marketing has a lot of strengths that include production and marketing of high quality milk and dairy products, increased shelf life, credit development, easy monitoring and supervision of quality standards and supporting an organized and elaborate nation-wide milk collection. The study noted, the most common formal marketing of milk in Bungoma County was through contract and cooperative marketing.

\section{(a) Contract Marketing}

The study observed that contract marketing existing between the large scale milk processors such as New KCC, Brookside Dairies, Daima Dairies and the Farmer Co-operatives. The study established that the farmer co-operatives would enter into milk delivery contracts with these processors to supply them with raw milk over a specified period of time ostensibly 6 months to 1 year. Key informant interviews with the managers of the cooperatives further revealed that the contracts would be initiated and drafted by these multi-million companies and as such, the farmer cooperatives had no obligation negotiating the terms and conditions applicable in such contracts. Smallholder dairy producers engage in contract marketing to manage risks in production and marketing, to share risk and to access credit. The most important reasons why producers are motivated to engage in contract marketing include guaranteed sales, stable prices, pre-payment, access to credit and access to inputs and assistance. Further, the study noted that contract marketing has the capacity to market dairy products through various ways of advertisement in print, electronic and events that increases demand for milk products. This demand consequently leads to demand for raw milk forcing milk prices to go up. 
The study also noted that contract marketing channels do value addition turning raw milk into various products such as powder milk, UHT with long shelf life, butter, cheese. These products are sold at fairly good prices which indicate that dairy farmers stand to benefit from sell of milk. However, one of the discussants in the focus group discussions decried the low prices offered to them by the contract agreement despite their capability to turn milk into more than 10 dairy products. Further, it was revealed that farmers should earn $40 \%$ of the milk being sold to the final consumers which was not achieved as the contractors bought milk at low prices and sold them at higher prices to final consumers making more than $100 \%$ profits.

According to Bijman (2008), smallholder's dairy farmers engage in contract marketing for the following reasons: access to markets and market information, access to technical assistance, access to credit and inputs, higher income and status and reduction of market and production risk. He further confirmed that if producers engage in contract marketing, they will get sound returns which improve their livelihoods and incomes. On the contrary, contract marketing, according to Swinnen and Maertens (2006) has a negative effect to the producer, such as long delays in payment, non-payments for delivered products or non-delivery. Singh (2002) further notes that contract marketing is a means of exploitation of farmers by agribusinesses/contractors due to unequal power relations. He also examined the demerits of contract marketing for producers such as, loss of autonomy / flexibility, lack of transparency (particularly in price determination), contractors might renege on contract, risk of indebtedness and adverse gender effect.

\section{(b) Cooperative Marketing}

The results revealed that some farmers sold their milk to cooperative societies which later sold it to milk processors or processed it to other dairy products through value addition. The importance of cooperative marketing gives farmers strong bargaining power to get high returns from dairy produce. The cooperative provides its members with a platform upon which they can run their dairy business with members' interests at heart. Further, cooperative societies were found to assist farmers in provision of information about the market, breeds, feeds, credit which was important for sustainability and increased milk productivity. However, the study noted that some cooperatives would offer dairy farmers prices below market value or they would impose hidden levies at the expense of the farmer. This discouraged the farmers from supplying milk to cooperative societies and they would prefer to sell it directly to consumers especially those who were offering better prices. Nandakumaran et al., (2008) indicated that in developing countries, the dairy cooperative has been recognized as an important means of organizing the supply of agricultural inputs, processing and marketing agricultural produce and providing agricultural credit, among other related activities. The fresh milk marketing through farmer cooperative system has proved to be an effective vehicle for livelihood development in general and for dairy development in particular in rural areas. Thampoe et al. (2010) revealed that the common need of milk producers is to obtain a fair price for their milk and this is fulfilled through collective marketing which should be sustainable and strategically adaptable.

\section{Marketing Framework}

Figure 3 below presents a schematic diagram of dairy product marketing channels currently adopted by actors in the dairy value chain in Bungoma County.

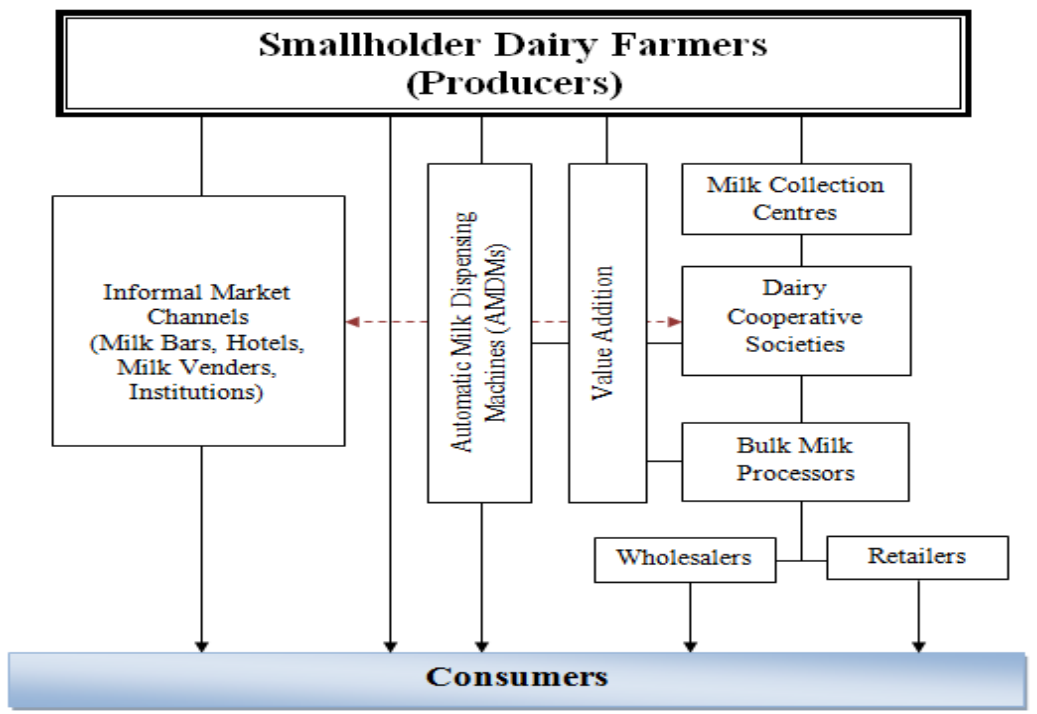

Figure 3: Marketing Model Adopted by Dairy Farmers in Bungoma County, Kenya Source: Field Data, (2016) 


\section{Factors Influencing Marketing Strategies}

The study sought to find out factors that influence marketing strategies adopted by dairy farmers in Bungoma County. The results are as shown in Figure 4

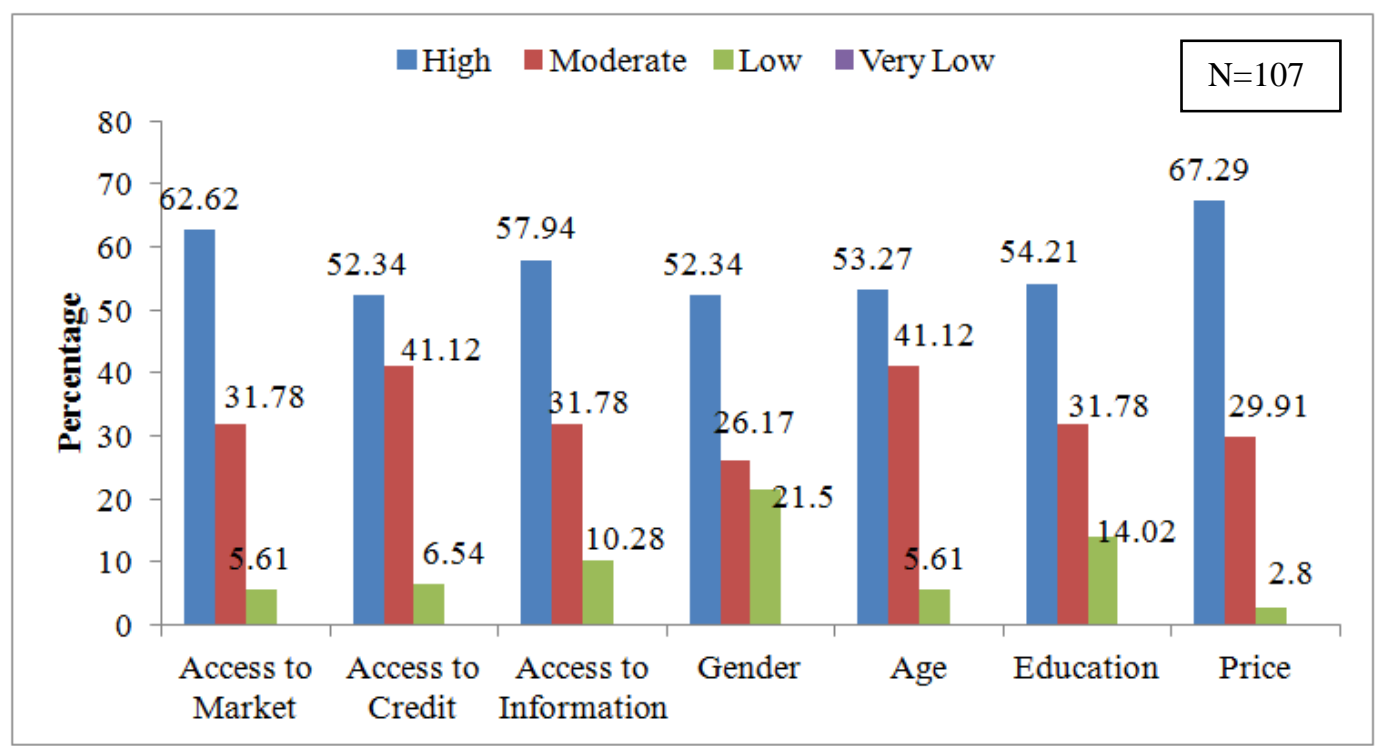

Source: Field Data, (2016)

Figure 4: Factors Influencing Marketing Strategies in Bungoma County, Kenya

From Figure 4, 62.62\% of the dairy farmer respondents revealed that access to the market influenced their decision on how to market their dairy products. Chi-square test conducted on access to market gave $\left(\chi_{2,0001}^{2}=63.159\right)$ which showed that there was highly significant $(\mathrm{P}<0.05)$ variation on market

accessibility. It was revealed that those who are near the cooperative societies would easily deliver their produce to these facilities. Further, the study noted that those farmers near urban centers preferred to sell their milk to milk bars; hotels and restaurants while those close to institutions like schools and colleges would prefer to sell them due ease of access to their nearest market or point of sale. This informal marketing was favored because the farmer is assured of ready cash.

From Figure 4, 52.34\% of farmer respondents revealed that access to credit influence their dairy products marketing strategies. Majority of the farmers were found to be earning less than Ksh. 10,000.00 per month which limits their ability to adopt better marketing strategies that require substantial capital. Most of the farmers accessed credit from sale of farm produce, sale of livestock, sale of other farm products (firewood/trees etc.). Others engaged in regular employment, casual employment (both agricultural and non-agricultural related), running own business and enterprises. The results from FGDs revealed that credit is needed to transport milk to the market as well as buy the containers that are need for transporting and storage of milk. The Interview with the livestock officers and cooperative managers also confirmed that low accessibility to credit facilities has opened avenues for exploitation by the middlemen who in some cases, buy milk from farmers at lower prices and resell it at higher prices.

From Figure 4, 57.94\% of the dairy farmer respondents revealed that access to extension information and services influenced their decision on dairy product marketing strategies. Chi-square test conducted on access to extension information and services gave $\left(x_{20001}^{2}=37.813\right)$ which showed that there was significant

$(\mathrm{P}<0.05)$ variation on extension information and services accessed by dairy farmers. Some of the dairy farmers in Bungoma County lack extension services which are needed to increase their milk production. This resulted in low production/outputs which could only be marketed informally. The interview with livestock officers revealed that those who were in position to afford extension services would produce large quantities of milk and would market their milk through formal marketing channels particularly contract marketing.

The demographic characteristics found to influence marketing strategies of dairy products include age, education and gender. The results from Figure 4 revealed that education highly influenced milk marketing strategies by $54.21 \%$. Majority of the respondents in this category lacked information about the milk market and the middle men would exploit them because of their ignorance. Age also influenced milk marketing strategies by $53.27 \%$. Most young male would use their bicycles or motor cycles to ferry milk to consumers. The influence of gender on milk marketing strategies was found to be $52.34 \%$. Majority of female dairy farmers sold their 
milk informally to their neighbors as well as hawking especially when the supply is high against demand. Male and more educated dairy farmers (college education and above) were found to market their milk through formal channels.

Source of information about production and marketing also influenced the marketing strategies adopted by dairy farmers. Majority of the dairy farmer respondents $(87.56 \%)$ obtained dairy market information from fellow farmers since they were in close contact with them and they found this to be effective. Other sources of market information that was extensively used included market place $45.6 \%$, traders $45.6 \%$, family and friends $56.7 \%$ and farmer organization $47.8 \%$. Farmers were found to believe their fellow farmers from what they have achieved through the marketing. However, majority of this information was based on informal marketing of milk products. The traders were found in some cases to misinform the farmers about market situations thereby commanding low prices of milk which affected the farmers negatively getting low returns. Farmers' organizations were also found to be used by farmers but not frequently. The main reason was that the scheduled meetings were not frequently done and in some cases they would meet once in a month. Therefore, they lacked information about formal dairy marketing which is considered a more stable marketing strategy for better returns.

Pricing of milk was found to influence the marketing of dairy products in Bungoma County as shown by $67.29 \%$ of the respondents. Chi-square test conducted on pricing gave $\left(\gamma_{2001}^{2}=55.533\right)$ which showed that

there was significant $(\mathrm{P}<0.05)$ variation on pricing of dairy products. Dairy farmers fear selling on credit which is the practice of most formal markets where milk is delivered and payment is made at later date. They need instant cash to pay for school fee, buy food for their family as well as adopt dairy production technologies in the dairy value chain.

This study established that market price for both raw and processed milk varies across the county. In Tongaren Sub-County for instance, the Naitiri Dairy Farmers Cooperative (NADAFA) purchases raw milk at a negotiated price of Ksh. 33/-, Kaptama Ksh. 30/-, Kitinda Ksh. 37/-, Tongaren Ksh. 27/-per litre during the dry season and the price fluctuate downwards to as low as Ksh. 20/- during the rainy season. NADAFA on the other hand retails processed milk at Ksh. 50/- per litre fresh milk being the only product they deal in at the time of the survey. A community based group (Top-Food Dairy) in Ndalu buys farmers' milk at Ksh. 30 per litre and processes it into various products including yoghurt, pasteurized milk, cream and mala. The prices were seen to further fluctuate upwards in sub-counties hosting the major towns such as Bungoma, Webuye and Kimilili. In Bumula and Kanduyi sub-counties, raw milk was purchased from farmers at Kshs. 40/- per while prices for processed milk varied based on the product. Yoghurt goes for Ksh. 50/- to Ksh. 60/- per 1/2 a litre depending on the location.

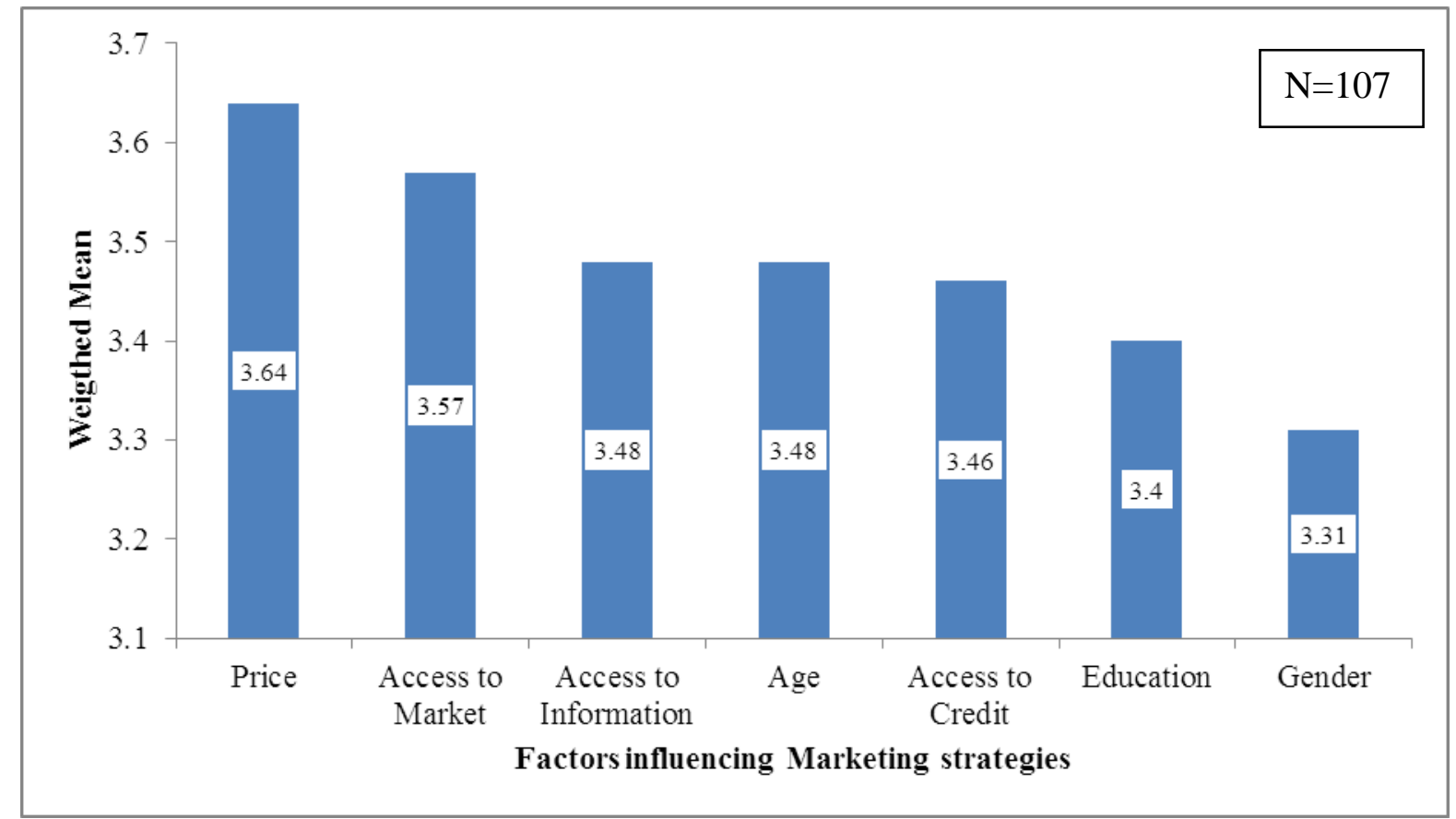

Figure 5: Ranking of Factors Influencing Marketing Strategies in Bungoma County, Kenya

Source: Field Data, (2016) 
According to Ndinomupya (2010), educational level of the farmer was found to be significant and positively influencing market choice and participation. Shiimi et al. (2010) concluded that the choice of a marketing channel by dairy farmers heavily depended on the price offered by that channel. Nardos (2010) indicated dairy product marketing in Ethiopia is limited by the distance of the market from producers; access for credit and availability of market information. Kigathi (2016) found out that in Kiambu County, market accessibility was the main factor influencing marketing of milk product in the county.

\section{Food and Nutrition Security Scarcity of Food}

The respondents were required to state which years between 2010 and 2015 did they experience scarcity of food in their family. The years identified were 2011, 58.7\% (55) and 2012, 41.3\% (38). Further the study noted that, in 2015, 67.4\% (62) of the respondents did not have enough food to meet their family needs. The months they faced severest food shortage were between January and March, 23.9\% (22) as well as between April and June, $76.1 \%$ (70).

The results further revealed that more than half of the respondents $56.1 \%$ (60) worried about scarcity of food in the past one month and there was no significant variation between those who worried and those who did not worry $\left(\chi_{1001}^{2}=2.783\right)$ showed that there was no significant $(\mathrm{P}=0.095)$. Similarly, within those who worried,

there was no significant variation on how often it happened as $\mathrm{P}=0.332$ with once or twice per month $41.3 \%$ (25) and more than 10 times per month $58.7 \%$ (35). The composite findings are as shown in Figure 6.

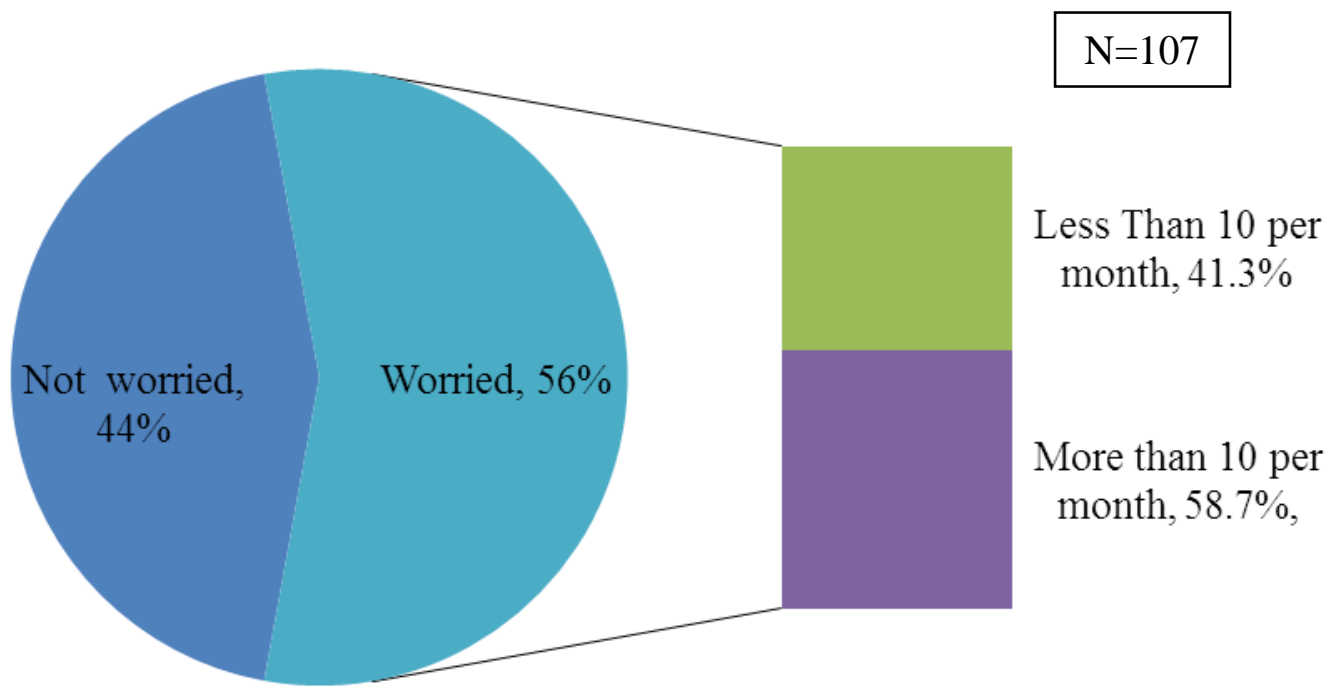

Figure 6: Farmers' Attitude on Food Availability in Bungoma County, Kenya

Source: Field Data, (2016)

\section{Insufficient Food Intake}

The results revealed that more than half $75.0 \%$ (69) of the farmer respondents affirmed that they or their household members ate smaller meal than what they needed because the food was not enough. Chi-Square value $\left(\chi_{1001}^{2}=23.00 \mathrm{y}\right.$ showed that there was significant $(\mathrm{P}<0.01)$ variation in response eating small meal than

needed because of insufficiency in Bungoma County. On having fewer meals a day, 54 (58.7\%) of the farmer respondents indicated that they ate fewer meals in a day because food was not enough. Chi-Square value $\left(\chi_{1001}^{2}=2.783\right)$ showed that there was insignificant $(\mathrm{P}=0.095)$ variation in response to having fewer meals in a day in Bungoma County.

More than half of the respondents, $73.9 \%$ (68) revealed that there was no food of any kind to eat due to lack of resource to get food. Chi-Square value $\left(\chi_{1001}^{2}=21.043\right)$ showed that there was significant $(\mathrm{P}<0.01)$ variation in response to no food to eat due to lack of resource in Bungoma County. However, 41.3\% (38) indicated that members of their household went to sleep without food. Chi-Square value $\left(\chi_{1}^{2}\right.$ ond $\left.=2.783\right)$

showed that there was insignificant $(\mathrm{P}<0.01)$ variation in response to going to sleep on empty stomach due to lack of food in Bungoma County. Similarly, less than half of the respondents confirmed that they or member of 
household went for a day and night without food due to insufficiencies. Chi-Square value $\left(\chi_{1001}^{2}=5.261\right)$ showed that there was significant $(\mathrm{P}<0.05)$ variation in response to spending day and night without food in Bungoma County. The findings are presented in Figure 7.

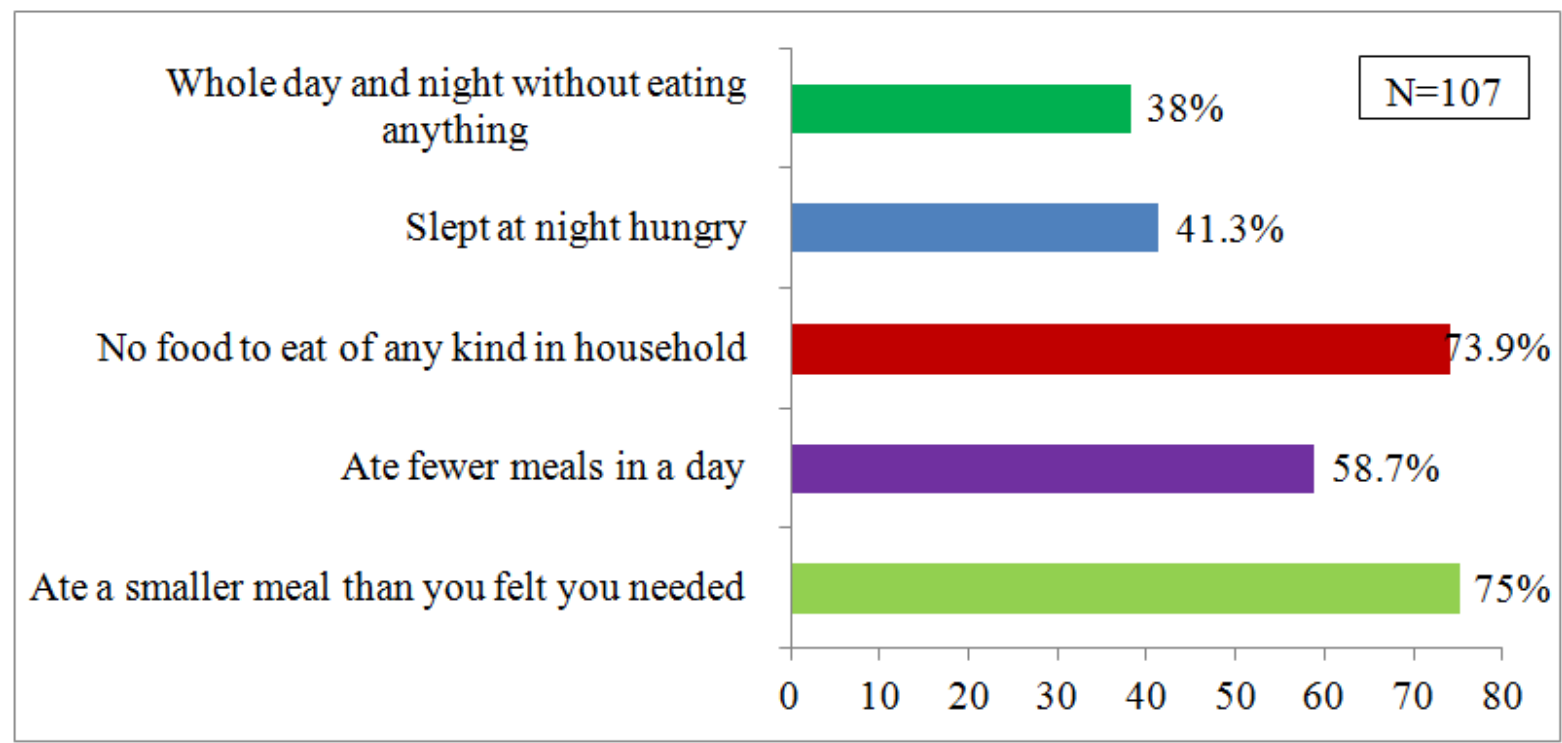

Figure 7: Insufficiency Food Intake and its Consequences in Bungoma County, Kenya Source: Field Data, (2016)

Food insecurity is still rampant in the county as indicated by the inadequacy, insufficient quality and frequency of food availability. This finding is similar to what was found by the household baseline survey done by KARI(2013) and Wabwoba et al. (2016) in Bungoma County, where they found between May and June to be a difficult month for most households in terms of food security. The household resorted to all sorts of survival means to cope with hunger including reducing the quantity, quality and frequency of eating in a day.

\section{Effect of the Dairy Marketing Strategies on Food and Nutrition Security}

This section correlates dairy marketing strategies with food and nutrition security in Bungoma County. The aim of this test is to find the effect of marketing strategies on dairy returns and food and nutrition security. This was achieved using spearman Rank correlation at 0.05 significance level. The results are presented in Table 1 below.

Table 1: Correlation of Marketing Strategies and Food and Nutrition Security

\begin{tabular}{|c|c|c|c|c|c|c|}
\hline \multicolumn{2}{|c|}{ Spearman's rho } & Direct & Itinerants & Cooperative & Contract & FN \\
\hline \multirow{3}{*}{$\begin{array}{l}\text { Direct to } \\
\text { Consumers }\end{array}$} & Correlation Coefficient & 1.000 & & & & \\
\hline & Sig. (2-tailed) & 0.000 & & & & \\
\hline & $\mathrm{N}$ & 107 & & & & \\
\hline \multirow{3}{*}{ Itinerants } & Correlation Coefficient & 0.070 & 1.000 & & & \\
\hline & Sig. (2-tailed) & 0.507 & 0.000 & & & \\
\hline & $\mathrm{N}$ & 107 & 107 & & & \\
\hline \multirow{3}{*}{ Cooperative } & Correlation Coefficient & 0.007 & $0.717^{* *}$ & 1.000 & & \\
\hline & Sig. (2-tailed) & 0.748 & 0.000 & 0.000 & & \\
\hline & $\mathrm{N}$ & 107 & 107 & 107 & & \\
\hline \multirow{3}{*}{ Contract } & Correlation Coefficient & 0.018 & $0.700^{* *}$ & $0.779^{* *}$ & 1.000 & \\
\hline & Sig. (2-tailed) & 0.764 & 0.000 & 0.000 & 0.000 & \\
\hline & $\mathrm{N}$ & 107 & 107 & 107 & 107 & \\
\hline \multirow{3}{*}{$\begin{array}{l}\text { Food } \\
\text { Nutrition }\end{array}$} & ${ }_{\text {Correlation Coefficient }}$ & $0.388^{* *}$ & $0.352^{* *}$ & $0.516^{* *}$ & $0.413^{* *}$ & 1.000 \\
\hline & ${ }^{\text {and }}$ Sig. (2-tailed) & 0.000 & 0.001 & 0.002 & 0.002 & 0.000 \\
\hline & $\mathrm{N}$ & 107 & 107 & 107 & 107 & 107 \\
\hline
\end{tabular}

**. Correlation is significant at the 0.01 level (2-tailed).

*. Correlation is significant at the 0.05 level (2-tailed).

Source: Field Data, 2016 
Effect of Marketing Strategies on the Dairy Value Chain Returns and Food and Nutrition Security..

\section{Effect of Direct Marketing Strategies on Food and Nutrition Security and Sustainable Development}

To get the effect of direct marketing strategies on food and nutrition security, the study performed spearman rank correlation of direct marketing strategies as independent variable and food and nutrition security as dependent variable. The results indicated that direct marketing as a marketing strategy in Bungoma County had significant moderate effect on food and nutrition security $(\mathrm{r}=0.388 * *)$. This implies that dairy farmers are able to cater for their food and nutrition through selling directly to consumers as they are assured of prompt payment. Farmers can also dictate the price of their milk products especially during scarcity of milk where the price is encouraging.

However, during rainy season with over supply of milk, farmers who sell their milk directly face competition resulting in low returns from their dairy farming. This kind of marketing of dairy products is not sustainable in the long run as farmers are not able to make meaningful investments in dairy farming. It is difficult for famers to increase herd size, acquire land for fodder production, adoption of breeding technologies and health technologies. All of the income that is realized is spent on daily household expenditure and little is left for healthcare, education and improvement of housing structure both for dairy cattle and household.

\section{Effect of Itinerant Marketing Strategies on Food and Nutrition Security and Sustainable Development}

To establish the effect of itinerant marketing strategies on food and nutrition security, the study performed spearman rank correlation of itinerant marketing strategies as independent variable and food and nutrition as dependent variable. The results indicated that itinerant marketing strategy in Bungoma County had significant moderate effect on food and nutrition security $(\mathrm{r}=0.352 * *)$. This implies that increase in milk sales among hawkers, vendors with AMDMs and the middlemen in general would result to increased food security but comparable to direct marketing of dairy products. However, under this approach, the milk is sold at comparatively lower prices than that sold to consumers directly thereby lowering the profit margins of the producers. The farmers offer prices of their products based on the information provided to them by these middlemen. As a result, farmers are likely to incur losses during high supply and low demand periods.

Effect of Cooperative Marketing Strategies on Food and Nutrition Security and Sustainable Development

To establish the effect of cooperative marketing strategies on food and nutrition security, the study performed spearman rank correlation of cooperative marketing strategies as independent variable and food and nutrition as dependent variable. The results revealed that cooperative marketing strategies in Bungoma County had significant moderate effect on food and nutrition security $\left(\mathrm{r}=0.516^{* *}\right)$. Marketing through this strategy gives farmers strong bargaining power in dictating the price of their products unlike selling individually. Dairy cooperative marketing presented long term gains to farmers more as an organized group rather than as individuals. Dairy cooperatives have the capacity to perform value addition on milk thereby increase the product base offered to customers. The cooperative societies in partnership with bulk processors would be able to facilitate adoption of various technologies in dairy value chain such as breeding, feeding and health.

However, there are few members in these cooperative societies who would prefer to sell it directly to consumers for immediate returns on their produce. Some of the farmers revealed that their colleagues with low income returns from other occupation were found to be less involved in cooperative societies as they were not willing to wait for a fortnight to be paid their dues.

\section{Effect of Contract Marketing Strategies on Food and Nutrition Security and Sustainable Development}

To establish the effect of contract marketing strategies on food and nutrition security, the study performed spearman rank correlation of contract marketing strategies as independent variable and food and nutrition as dependent variable. The results indicated that contract marketing strategies in Bungoma County had significant effect on food and nutrition security $\left(\mathrm{r}=0.413^{* *}\right)$. This implies that increase in contract marketing strategies such as the contract with milk processors would result to increase in food security and nutrition. Like cooperative marketing, contract marketing is ideal for transformation of the dairy value chain in terms of payment modes thereby enhancing adoption of dairy technologies. However, unlike cooperative societies, farmers in contract marketing have no control over milk prices and they do not enjoy privileges through cooperative marketing.

\section{Overall Effect of Marketing Strategies on Dairy Returns, Food and Nutrition Security and Sustainable Development}

Multiple Regression analysis was used to find to the overall effect of all marketing strategies of dairy products on food and nutrition security. This aided in coming with $\mathrm{R}^{2}$ which determined by the percentage change in food and nutrition that is been accounted by marketing strategies of dairy products in Bungoma County. The results are as shown in Table 2 below. 
Effect of Marketing Strategies on the Dairy Value Chain Returns and Food and Nutrition Security..

Table 2: Overall Effect of Marketing Strategies Return on Food and Nutrition Security and Sustainable Development

\begin{tabular}{|c|c|c|c|c|c|c|}
\hline \multicolumn{7}{|c|}{ Model Summary } \\
\hline Model & $\mathbf{R}$ & \multicolumn{2}{|c|}{ R Square } & Adjusted R Square & \multicolumn{2}{|c|}{$\begin{array}{l}\text { Std. Error of the } \\
\text { Estimate }\end{array}$} \\
\hline 1 & $.523^{\mathrm{a}}$ & .273 & & .231 & \multicolumn{2}{|c|}{.43417} \\
\hline \multirow{2}{*}{\multicolumn{7}{|c|}{$\begin{array}{l}\text { a. Predictors: (Constant), Dairy Product Marketing strategies } \\
\mathbf{A O V}\end{array}$}} \\
\hline & & & & & & \\
\hline \multicolumn{2}{|c|}{ Model } & Sum of Squares & Df & Mean Square & $\mathbf{F}$ & Sig. \\
\hline \multirow[b]{2}{*}{1} & Regression & 6.093 & 5 & 1.219 & \multirow[t]{2}{*}{6.465} & \multirow[t]{2}{*}{$.000^{\mathrm{b}}$} \\
\hline & $\begin{array}{l}\text { Residual } \\
\text { Total }\end{array}$ & $\begin{array}{l}16.211 \\
22.304\end{array}$ & $\begin{array}{l}86 \\
91\end{array}$ & .189 & & \\
\hline
\end{tabular}

a. Dependent Variable: Food and Nutrition Security

b. Predictors: (Constant) Dairy Product Marketing Strategies

\section{Source: Field data (2016)}

The coefficient of correlation was 0.523 , $(\mathrm{r}=0.523)$. The coefficient of determination $\left(\mathrm{r}^{2}\right)$ was 0.273 , and this shows that $27.3 \%$ of the variation in the food and nutrition security can be explained by the dairy product marketing strategies in Bungoma County and the remaining $72.7 \%$ of the variations in food and nutrition security can be explained by other factors not in this study. From the ANOVA results the F test gave a value of $F(5,91)=6.465, p<.01$, which was supports the goodness of fit of the $\mathrm{R}^{2}$ in explain change in food security and nutrition as a result of dairy marketing strategies.

This indicates that marketing strategies of dairy products has significant effect on dairy returns, food and nutrition security and sustainable development in Bungoma County. Various studies have revealed that marketing strategies plays significant role in food security. FAO (2011) indicated that dairy farming provides regular returns to farmers from informal market, especially to women, enhances household nutrition and food security and creates off-farm employment. Mwakalobo and Shively (2001) noted that increase in income from dairy product marketing increases the ability to purchase food for the family to curb the food insecurity situation in more than $40 \%$ of the poor families in the tropics. Kariuki et al. (2015) indicated the informal dairy marketing plays a significant role in food and nutrition security by improving livelihoods with a trickledown effect on their community. However, informal milk traders often cite the lack of sustainability of their businesses given the erratic supply of milk: during periods of excess supply (glut), the price of milk drastically falls making it difficult for them to make profits which would otherwise invested (Republic of Kenya, 2011).

\section{Conclusions}

Most of the dairy products were marketed through informal marketing strategies such as direct sales to consumers or through middlemen. A small segment of the farmers marketed their products through formal outlets such as contract and cooperative marketing options. Informal marketing strategies were unsustainable to dairy farmer's household in long term development as the returns were unsustainable and unpredictable. This resulted in food scarcity especially between the months of January and June as most households resorted to other coping strategies for survival such as reducing number of meals per day and limiting variety of foods. Returns from informal marketing were found to be insufficient to fully support family needs such education, shelter and health. Furthermore, investments in dairy farming and other forms of development are limited by the low returns.

\section{Recommendations}

The study recommends for concerted effort within the dairy value chain actors to improve returns from informal marketing to facilitate food security and sustainable development. This can be done by enhancing value addition to avail safe products on the shelf at various outlets. There is need to evaluate actual contribution of dairy in food security with a view to enhancing its role. There is also need for flexible contract marketing of dairy product which would ensure farmers are able to earn more than $50 \%$ of processed dairy proceeds. There is need to evaluate the role organized informal marketing with a view to consolidating returns from the approach 


\section{Acknowledgement}

The authors would like to thank Prof. Jacob W. Wakhungu of Department of Disaster Management and Sustainable Development, Masinde Muliro University of Science and Technology for his valuable contributions to this article.

\section{Reference}

[1]. ADCE (2011). Tanzania dairy industry status, opportunities and prospects. Morogoro

[2]. Bijman, J. (2008). Contract Farming in Developing Countries: An Overview. Working Paper. Retrieved March 17, 2009, from www.mst.wur.nl

[3]. DDA (2010). Dairy Development Authority Annual report. Ministry of Agriculture, Animal Industry and Fisheries.

[4]. Elepu .G, (2006).Value chain analysis for Dairy subsector in Uganda. Adraft report submitted to ASPS Uganda Agribusiness Development component. Un published.

[5]. FAO (2007).The State of Food Insecurity in the World 2007: High Food Prices and Food Security - Threats and Opportunities, Rome: FAO

[6]. FAO, 2015. The State of Food Insecurity in the World-Meeting the 2015 International Hunger Targets: Taking Stock of Uneven Progress. Food and Agriculture Organization of the United Nations, Rome.

[7]. FAO. 2014. Case studies in small-scale agriculture and fisheries subsectors. Food loss assessment: causes and solution. Kenya. Banana, Maize, Milk, Fish (available at FAO Save Food Initiative: www.fao.org/fileadmin/user_upload/savefood/PDF/Kenya_Food_Loss_Studies.pdf).

[8]. IAC (2004).Realizing the promise and potential of African Agriculture. Amsterdam

[9]. IFAD (International Fund for Agriculture Development) (2015). Smallholder Dairy Commercialization Programme Additional Financing: Updated Programme Design Report. IFAD, Rome. 54p.

[10]. KARI (2011). Ministry of Agriculture, Livestock and Fisheries and Agricultural Sector Development Strategy Programme (ASDSP), Household Baseline Survey, Bungoma County, Government Printer, Kenya

[11]. Kariuki, C. (2015). Financing Agricultural Value Chain in Kenya: Challenges and Opportunities in the Dairy Subsector. Master Thesis. United States International University

[12]. Kibiego M, Lagat J, Bebe B (2015). Competitiveness of Smallholder Milk Production Systems in Uasin Gishu County of Kenya. J. Econ. Sustain. Dev. 6(10):39-45.

[13]. Kigathi, C. C. W. (2016). Motivating factors for dairy cooperative membership in Kenya: a case of small holder dairy farmers in Kiambu County (Thesis).Strathmore University.

[14]. Kristensen, E; Larsen, C. E. S; Kyvsgaard, N. C; Madsen, J and Henriksen, J. (2004). Livestock Production - The Twenty First Century's Food Revolution. Livestock Research for Rural Development.

[15]. MAAIF. (2004). Ministry of Agriculture, Animal Industry and Fisheries: Poverty Status report, Poverty Reduction and the national Development process. Reducing Vulnerability, Equalizing Opportunities and Transforming Livelihoods. Economic Development Policy and Research Department May 2004

[16]. Mwakalobo, A. and Shively, G. (2001).Food Security and Natural Resource Management in Developing Countries. Staff Paper No 1-12, Department of Agricultural Economic: Purdue University, West Lafayette Indiana.22pp.

[17]. Nassiuma, D. K. (2000). Survey and sampling: Theory methods, University of Nairobi press: Nairobi

[18]. Njuki, J., Kaaria, S., Chamunorwa, A., and Chiuri, W. (2011) "Linking Smallholder Farmers to Markets, Gender and IntraHousehold Dynamics: Does the Choice of Commodity Matter?" European Journal of Development Research 23(3): $426-443$.

[19]. Paris , T. R. (2000). Crop-Animal Systems in Asia. Socio-economic benefits and impacts On rural livelihoods, Agricultural Systems, 71: 147 - 168 .

[20]. Republic of Kenya (2011). Ministry of Livestock Development Dairy Commercialization Programme (SDCP): Final Report ;Volume1. Impact Assessment Study. Nairobi: Government Printers.

[21]. Rubin, D., and Manfre, K. (2012).Promoting Gender Equitable Opportunities in Agricultural Value Chains: A Handbook Washington, DC: United States Agency for International Development

[22]. Singh, S. (2002)."Contracting Out Solutions: Political Economy of Contract Farming in the Indian Punjab."World Development30(9): 1621-1638

[23]. Swinnen, J., \&Maertens, M. (2006).Globalization, Privatization, and Vertical Coordination in Food Value Chains in Developing and Transition Countries.Plenary 76 paper prepared for presentation at the International Association of Agricultural Economists Conference, Gold Coast, Australia

[24]. Wabwoba, M,, Wakhungu, J., \& Omuterema, S. (2016). Household Food Insecurity Coping Strategies in Bungoma County, Kenya.International Journal of Nutrition and Food Sciences. Vol. 4, No. 6, 2015, pp. 713-716. 